\title{
Systematization and the Model of Political Management in Contemporary Iranian Thinker's Idea
}

\author{
Aref Barkhordari \\ Assistant Professor Department of Political Thought, University of Tehran, 16 Azar St- \\ Enghelab St- Enghelab Square -Mailbox: 6619-14155 Tehran, Iran \\ Tel: 0989139791522 E-mail: arefbarkhordari@ut.ac.ir
}

Received: April 30, 2020 Accepted: May 28, 2020 Published: May 31, 2020

doi: 10.5296/jsss.v7i2.16937 URL: https://doi.org/10.5296/jsss.v7i2.16937

\begin{abstract}
The present article, with its analytical-descriptive method, will consideration the thought of the most prominent systematization thinkers of Iran in the contemporary era. Examining the opinions of some thinkers throughout history, it will be shown that some of them have always sought political systematization and a model of political management for the societies. Their goal and aspiration from the past to the present was achieve the societies and human beings to the happiness. The efforts of thinkers such as Plato, Aristotle, Farabi, Khajeh Nasir al-Din al-Tusi, Moore, Will Durant, Kant, Hegel, Marx, Popper, Russell, etc., indicate this situation. Among Iranian thinkers of the contemporary era also many efforts were made to achive the political systematization and the model of political management. Akhundzadeh, Malek Khan, Talibuv Tabrizi, Ayatollah Mirza Naeini, Ahmad Kasravi, Mohammad Ali Foroughi and Ayatollah Khomeini are among the thinkers who have theorized in this field and each of them has provided a model of political management for Iranian society. In the following, their thoughts will be investigated.
\end{abstract}

Keywords: Political systematization, Political management, Modernity, Tradition, Modern classics, Islam

\section{Introduction}

Some thinkers throughout history have always sought to systematization and provide a model of political management for human society. Works by philosophers such as Plato, Aristotle, Moore, Campanella, Hegel, Marx, Farabi, and Khaje Nasir al-Din Tusi illustrate this. Systematization thinkers usually enter their world of philosophical thinking on the basis of a system of thought, some based on theology, some on the basis of metaphysics and some on rational theories. This system of thought prepares the principles of their philosophical system 
and shows what the basis is for a philosopher. On the other hand, the outputs of any philosophical system are the product of the thinking of a philosopher. Since the systematization philosopher seeks to design an ideal state of human welfare, he does so on the basis of his intellectual foundations. A system is a set of elements that interact in a way that can be viewed as a system. Thus, the systematic philosopher, through the passage of his philosophical thought, builds upon the foundations of his philosophical thought that form these components in a harmoniously coherent whole and his goal is to build a system that creates a favorable situation for society. Contemporary Iranian thinkers have also made great efforts in the field due to the failure of the traditional system in the face of modernity. Some of these thinkers have sought to design a model that suits Western political systems through education and living in the West and understanding the modern world, Others have been influenced by Islamic and modern world concepts to design a model in which there is some consistency between the components of the modern world and Islam, Others sought to present a paradigm that was a combination of elements of ancient Iran and modernity, and ultimately some sought to present an Islamic political paradigm, in contrast to the West and modernity (Barkhordari, 2016). As mentioned earlier, Akhundzadeh, Malcolm Khan, Talibuv Tabrizi, Mirza Naieni, Kasravi, Foroughi, and Imam Khomeini are among the scholars who have theorized. Akhundzadeh, Malekam Khan and Talebov Tabrizi are first-class thinkers, Mirza Naieni from second-class thinkers, Mohammad Ali Foroughi and Ahmad Kasravi from the third category, and finally Ayatollah Khomeini, fourth-generation thinkers.

\section{Systematization and the Model of Political Management}

Until modernity came into Iranian society (19th century), a traditional discourse consisting of two elements of government and religion dominated Iranian society. The second pillar of this discourse, Shariah, was strengthened by the strengthening of the Shiite religion in the Safavid era. In other words, prior to the introduction of modern thought into Iranian society, there were two layers or structures of Iranian culture, one being the structure of ancient Iranian culture and civilization and the other, structure of Islamic culture. This discourse or semantic system ruled Iran until the time of the Qajar kings, but since the era of the Qajar kings modernity has invaded Iran during the Iran-Russia war and has invaded Iran's traditional discourse. In the process of modernization, these layers of culture and the intellectual system of Iranian society were damaged and there was tension between the traditional structure of Iranian society and modernity and subsequently caused intellectual, philosophical, political and social crises. (Of course, these crises also spread to Iran after the 1979 revolution, but we will refrain from explaining them)(Barkhordari, 2019). Thus, with the introduction of modernity into Iranian society, the traditional discourse that dominated Iranian society became increasingly critical, and eventually defeat this discourse at the end of the Qajar era. This crisis has engulfed Iranian society's thinkers for 150 years. Each will attempt to systematize and present a model of political management. Since the intellectual structure of each, was composed of different components, each presented its own model of management and political systematization, which we will discuss in the following.

Akhundzadeh is one of the first thinkers to theorize about political systematization and political thought. The principles of Akhundzadeh's philosophical thinking are based on the belief in the authenticity of matter and the denial of the single soul. He believes in the 
authenticity of reason and experience and believes in the relation between cause and effect and establishes the basis of ethics for reason, adopts the method of scientific criticism wherever it consists with the criteria of reason and science. His thinking begins with mere matter and leads to matter (Adamiat, 1971). Akhundzadeh speaks of such topics as constitutionalism and the rule of law, moderate or constitutional monarchy, rights to liberty, equality, reform of religion, criticism of authoritarianism and nationalism in his intellectual design and systematization.

Akhundzadeh's thinking was founded on natural social rights and believed in law and rational politics. At the heart of his ideas was the overthrow of the authoritarian state and the establishment of a constitutional government. He deals with the principles of the new Western government and the rule of individual rights and considers the source of power in the will of the nation. He describes the political system of Iran (King of Qajar) as a Despot and a Despot that is not a rule governed by law and dominates the lives and property of the people ... (Adamiat, 1971). In his criticism of the Qajar king, he says: "the king, unaware of the progress taking place in the world, has sit in his capital and thinks that throne means wearing sumptuous clothes and eating fine foods, and controlling the lives and property of the serfs and subordinates (Adamiat, 1971). Therefore, in the view of Akhundzadeh, firstly, the political system in Iran should be constructed on the constitution and the restriction of power; and secondly, the will of law should be binding upon the social council, the legalizing agent should be the parliament, the parliament should be formed of the representatives of the serf and the representatives of the noblesse, every law in the kingdom should be signed by the king after it is ratified by these two chambers before it is implemented, and the king should have no power to enforce against such acts (Adamiat, 1971). Akhundzade considers the constitutional government as a system based on a customary human, rational, statute constitution (Adamiat, 1971). Akhundzadeh uses the three foundations of the constitutional system: the rights to liberty, equality, and the change of authoritarian monarchy to moderate or constitutional monarchy. He argues that in civilized European countries the Constantinople Tutsi monarchy (Moderate Monarchy) was established (Adamiat, 1971) and moderate rule was the result of two developments: the evolution of the minds of sages and the efforts of patriots. He considers sages as pensur and pensur as a philosopher or sage philosopher who writes on the basis of reason in the politics of ballads. Revulsion is a condition under which people are frustrated by the despot and oppressive king and congregate to revolt and bring him down and set laws and adopt new styles for themselves under the administration of rationalist philosophers" (Adamiat, 1971). Akhundzade followed two distinct paths in his political thought and his aim was to overthrow the authoritarian absolutist state and transform it into a constitutional state; one was the prince who became a reference for socio- political reforms, and the other was the nation risen up, removed the State from power and brought reforms(Adamiat, 1971). Regarding the first path, he considered the previous kings as having had consumed, worn, kicked the bucket, and left nothing behind. He, therefore, states that the prince must follow the path of progress and win his people's hearts by striving for their growth and wellbeing. In the second place, he recommends the nation "Oh, people of Iran! If you knew of the joy of freedom and your human rights, you would have not consented to slavery and cruelty, would have sought knowledge, and opened freemasonry lodges and 
councils, you are grander in number and power than the despot, you only want unity and uniformity "(Akhundzadeh, 1979). In another part of his thinking, Akhundzadeh deals with nationalism, believing that, over time, religious beliefs in humans do not have the former effect of killing people in front of their enemies in order to maintain the authority of the nation and the state's grandeur. At this time, the nation's thinkers must have strategies for the authority of the nation and the protection of the homeland from alien domination and the rejection of captivity and lack of freedom and independence. The policy of removing this humiliation is in spreading the sciences throughout the nation and planting the seeds of zeal, patriotism and patriotism within them. Akhundzadeh in Love Homeland believes that: "as man's mental thirst is quenched by acquiring knowledge and surveying the laws of nature, his spiritual thirst is quenched by love of family and homeland too. (Adamiat, 1971) Akhundzadeh was well aware of the historical roots of the emergence of the new concept of Western patriotism and its political and ethical aspects, and knew that the establishment of new political systems in Europe and nationalism and political unity based on Christianity would be outdated and based on liberalism. On the other hand, his understanding of nationalism is so profound that he opposes despotism but prefers it on foreign influence. Akhundzadeh was deeply fascinated by ancient Iran and says with regret over the contemporary situation: "I wish if I'd not come to Iran and had not seen the condition of these people, my heart bled, oh, Iran! Where is your ancient glory and bliss when the great kings ruled you?"(Adamiat, 1971). Pity you O Iran! Your land is desolate and your people are ignorant, unaware of the civilization of the world, deprived of the blessings of freedom, and your king is despot (Adamiat, 1971. Barkhordari, 2020). He conceives of the reason for this backwardness to be State oppression and clerical fanaticism (Adamiat, 1971) and attributes the onset of the decline and the political and spiritual decline of Iranians to the Arab invasion. (Akhundzadeh, 1979). The other part of Akhundzadeh's thinking is Protestantism or reforming religion. He criticizes the foundations of religion with scientific thinking (Adamiat, 1971). He begins his discussion of the art of criticism and sees the progress of Europe as a result of criticism of religion and the development of science and technology, and therefore recommends that if they want to achieve civilization, science and technology, They should criticize religion (Adamiat, 1971). Ultimately, Akhundzadeh saw the solution to pain not in changing religion but in promoting the natural sciences and wisdom (Akhundzadeh: Molhaghat, 219-221). In another part of his system of thinking, Akhundzadeh talks about the issue of the Persian alphabetic and changing it from the traditional way, its relation to the intellectual and cultural stagnation and backwardness in society which we refuse to mention.

Malcolm Khan was another person who sought to systematize and present a model of political management. He pursued reform through the reinterpretation of religious and cultural traditions and sought to show compatibility between institutions and thoughts modern with religion. He researched the issues of reforming and advancing society in a systematic and scientific way, and he was one of the first thinkers to become aware of the political, social and cultural ideas of the modern world through the acquisition of modern science and natural wisdom in France and the political and social thinking of British thinkers, and to bring modernity into Iran. He began the plan of reforming Iran's affairs with the reform of the state and considers the condition of the reform of the state to accept the 
principles of the western state without considering the patriotic ideas. (Adamiyat, 1961).

He views government as a system that is formed in an independent nation and commands them and considers it two types: monarchy, republic. Whenever in one population the government is controlled by one person and the government is inherited in the family, it is a royal government and if the government is transferred to the people by law and one after the other, it is called republican (Adamiyat, 1961) In defining the law, Malcolm says "Law is any order that is determined by the state and is in the public interest. According to his definition of law, the government has two powers: Writing the law, the execution of law. According to these powers, he divides the monarchy into two parts: the absolute, moderate (Adamiyat, 1961). Absolute includes regular and irregular, In regular absolute monarchy although the king retains both legislative and executive powers thoroughly, But in order to maintain the order of the state and its own power it never mixes these two powers He never gives his ministers the power to enact and enforce the law, the two powers being completely different. In irregular absolute monarchy, the distinction between the two powers is not recognized and the two are exercised intermittently, while ministers take control over the king. The more separate the two powers are kept in an absolute monarchy, the higher is the power of the king. Monarchies of this characteristic have created two separate systems for enhancing order: enforcement and regulation (Adamiyat, 1961). On this basis, he considers the governance of western state based on the rule of law and considers the Iranian and Asian governance based on the arbitrary management. Malcolm sees the solution to the disadvantages and path of progress in Asian and Iranian countries in the rule of law through the House of Representatives (Adamiyat, 1961). Based on the aforementioned arguments, Malik Khan argues that the Iranian government should be based on absolute monarchy, but in his later writings he speaks of the limitation of monarchy rights and the sovereignty of the will of the nation as the source of law (Adamiyat, 1961). Malcolm goes on to discuss constitutional monarchy and parliamentary government. Concerning the establishment of the National Assembly and the delimitation of monarchy, Malcolm argues that the Lords of the land, elders and scholars must be brought together into one great national council and, as required by divine decrees, determine the limits of the monarchy and the rights of the people, justice and the means of prosperity and the accessories of general welfare as required by law. They would later enforce these sacred laws under the protection of the king, the guarantee of the responsible ministers, and assisted by the parliament. (Adamiyat, 1961). Malcolm was thinking of establishing two parliaments: the House of Representatives of the Nation, and the House of Representatives, which is composed of the scholars and the elders (Adamiyat, 1961) $\mathrm{He}$ also argues for the separation of the legislature from the executive in parliamentary government: Every government that wants to survive in financial and life security should have a parliament of law, and law enforcement has a special organization that in most states is called the Cabinet, the Ministers must be accountable to the Legislative Assembly and accountable for each other's actions in the service of state.( Adamiyat, 1961)

Another thinker was Talibuv Tabrizi. Modern scientific and philosophical topics are the basis of his system of thought. His political views are a combination of political liberalism and social democracy, and he seeks to establish a democratic system. Emphasizes the rights of freedom and the rule of law. Believes in an elite government. Rationalizing politics is one of 
his main concerns. In separating from traditional political ideas, Talibuv based his thinking on liberalism and socialism and discussing concepts such as freedom, natural rights, social contract, law and sovereignty.

On the issue of sovereignty, Talibuv considers the government to be the people who give it to one family as monarchy and give it to another family if that family does not deserve it (Talibuv, 1906 (c). Also influenced by John Locke, he also prescribes the right of the rebellion to the people of society against the deviation of sovereignty (Adamiyat, 1985). Talibuv differentiates between government, State, nation, and the society. He believed that the kingdom or government consists of one or more lands and nations. A nation is the group of human society, land as home or residence of that human society. Talibuv names the head of each state with one name. Some are referred to by the king and emperor and generally in their oral form as crowns and in essay form in the highest authority of the Prophet (Talibuv, 1977). Talibuv regards government as three types: the first is totalitarian despotism, which is divided into two types: absolute rule by the law of the king's own and absolute rule without law. The second is the constitutional monarchy with a bicameral parliament and the third is the republic with the president-elect of the people (Talibuv, 1977. Talibuv, 2015). Talibuv criticizes despotism and praises constitutional regimes and calls for their formation. He considered two parliaments for the constitutional regimes: the Senate or the nobleman, appointed by the King, and the House of Representatives or the nation-elect (Talibuv, 1977). Talibuv criticizes autocracy. In his view, the throne of that government is inherited, the ministers are accountable only to the king. Absolute government has no law, and if there is a law, its writing and enforcement are mixed, the people's lives and property are in the king's hands. (Talibuv, 1977). Talibuv considers freedom in the paradigm of modernity as the legal and social meaning and the central factor in the promotion of modernity. In his view, freedom means being free from all constraints. He also regards freedom as equality.Freedom means indifference. Talibuv considers freedom from natural rights and he mentions six forms of freedom as: identity, beliefs, expression, press, assembly, and election (Talibuv, 1906/1324 $\mathrm{AH})$. Another issue of interest to Talibuv is the question of law and its foundation. Unlike his predecessors, he saw the law not in heavenly laws and hereditary authority but in the will of the nation, and he considered the law to be of two kinds: material and spiritual. Spiritual laws are laws that the prophets expressed through revelation; material laws such as civil and political law are made by the wise. (Talibuv, 1977). Talibuv regards legislation from the prerogatives of people and for the benefit of the public. He does not deny the necessity of the religion and the laws of the prophets but considers them far from the affairs of the country and the material aspects of life (Talibuv, 2015). Talibuv also speaks about the constitution and considers it to determine the rights of the king and nationals of the country. In his opinion, the constitution should be drafted in parliament. Talibuv also speaks about the constitution and considers it to determine the rights of the king and inhabitants of the country. In his opinion, the constitution should be drafted in parliament. He considers parliament to be the institution of law and order (Talibuv, 2015). and the ministers will be accountable to parliament if they fail to perform their duties or execute the king's illegal order. (Talibuv, 2015).Nationalism is another issue of interest to Talibuv. He considered homeland love from to homeland and believed that human zeal, dignity and nervousness were only in preserving the dignity of the 
homeland, honoring the homeland, increasing the wealth of the homeland, educating the Childs of the homeland, and action to the homeland's religion and traditions. (Talibuv, 2015).

Mirza Naieni is another thinker who has theorized about the systematization and model of political management. He is one of the scholars who sought to reconcile the components of the modern world with those of the Islamic world. Under the influence of new information and awareness of the social reality of Iran, Naieni favored parliamentary and constitutional democracy and provided a religious narrative of constitutionalism. He was a confluence of two streams of religious tradition and modern thought. In his Thesis he tries to prove that there are constitutional principles such as freedom, equality, parliament, separation of powers and legislation within the religion. Naieni sees government as two types: despotic and constitutional. In despotism, the governors regard the government as their right and the state under the control of the government as their fief. The constitutional system is the Management and Governance on fulfilling the duties of order and preserving the country, and is a trust to apply the powers of the state to order and preserve the country, not for its own lusts. Therefore, the sultan's control over affairs is limited and his possession of the affairs, whether right or by force, will be limited and conditional. In his view, the best method of preventing the constitutional government from turning into despotism is the infallibility and purity found in the principles of the Shiite religion (the Twelve Imams Shiite) and in the Imam. (Naieni, 1982). In Naieni's view, since there is currently no access to that pure and infallible Imam, therefore, there is a need to establish a constitutional parliament in compliance with religion and restricting the absolute government. From the point of view of Naieni, monarchy other than the infallible Imam is usurped, and the government is the sole right of the infallible Imam and his successors (Ajudani, 2005), but in a situation where the infallible Imam is absent from view and the government is in the hands of the oppressive rulers, the ruler should not be allowed to do bullying acts. Therefore, a method is needed to prevent oppression and create order in society. Naieni therefore advocates constitutionality and considers it a state that establishes order and prevents oppression (Abadian, 1995). Naieni views tyranny as a system that does not rely on any law or ethics and is a tyrant who views the country and the people as his personal possessions and treats people as slaves and animals. Naieni calls the authoritarian regime a despot, ownership, despotism, subjugating, coercive, domineering, and imperialism, and he considers the despot to be an absolute and cruel ruler (Naieni, 1982). Naieni describes tyranny as two types: First: political tyranny, the origin of this kind of despotism is dominating the bodies. Second: Tyranny based on deception, the origin of this kind of despotism is dominating the hearts (Abadian, 1995). Naieni considers the constitutional government to be free from any tyranny and ownership of the people, and believes that such a system is based on certain duties and the power and authority of the rulers to perform certain duties. In such a system, all people in the finance and other affairs of the country have equal rights with the King. Naeini calls such a government as restricting, controlling, just, conditional, responsive, and imperative (Haeri, 1986). Naieni describes Islam as the starting point for his discussion of the constitutional government, and he attempts to reconcile the new political institutions with Islam and the Shia, showing that the Shi'ism offered the most complete form of government. From the Naieni'i point of view, government is the only right of the infallible Imam, but when the 
infallible and pure Imam is hidden from view, the only method of Governance that can replace the Imam's rule is a constitutional system (Naieni, 1982). Naienien believes that two steps must be taken before a constitutional regime can perform its task: First, a constitution must be written that sets out the limits of the power of the sultan and the freedom of the nation and the rights of all classes of people based on religion. Second, the holding of a National Assembly and the presence of people's representatives in it (Haeri, 1986). Naienien also divides the administration into two legislative and executive branches, and expresses his views on the legislative powers of parliament.

Another thinker who theorized about systematization and the model of political management was Mohammad Ali Foroughi. He is a thinker of the third category, that is to say, he sought a model composed of the components of ancient Iran and modernity. Foroughi pursued the greatness of ancient Iran and drew a pattern for the development of new Iran. He looked at the history of Iran and its factors of greatness and decline with a scientific view and did two things in this regard: "First, he linked the tendency to the ancient with the phenomenon of nationalism in Iran, and used it as the main pillars of the national and modern government of Reza Shah. Second, he linked his ancientist ideas realistically to the new world conditions and cultural exchanges between nations and the issue of tourism, preserving the antiquities and reinforcing the spirit of nationalism as a pride of Iranians at the present time (Haghdar, 2005). Emphasizing on modern political ideas and focusing on man and his modern political and social rights, Foroughi wrote a Thesis on Fundamental Rights. In this book, Foroughi first deals with the origin of the state and considers the concept of social contract as the origin of the state formation (Foroughi, 2004). Foroughi goes on to divides governments in terms of compliance and non-compliance with laws, and also based on the shape and style of government. The government that is bound with the determined limits of the ruler and the providence of people's rights, is constitutional and genuine, and the one in which the State's power and the people's rights is not respected, a baseless state (Foroughi, 2004). He divides the state into two forms: royal (tyrannical) and republic (constitutional). In despotism, power is in the hands of one person and is inherited from the family. In constitutional government, power is in the hands of a select community, and the function of power-holders is restricted by law. (Foroughi, 2004). The constitutional government is synonymous with the genuine government on Foroughi's view, and is based on two principles, national government and the abdication of government authority(Foroughi, 2004). Foroughi considers the duties of a constitutional government preserved the rights of the people and considers it a duty of the state that act by law. Foroughi does not consider the law to be feasible except with the enactment of the law and its continuous implementation. Therefore, in his view, the government has two powers: enact the law, enforce the law (Foroughi, 2004) Foroughi considers the parliamentary system the most reasonable way of executing such a situation, and defines parliament as the council that bears the responsibility of defining laws and are representatives of people; he also believes in the separation of the legislative and administrative bodies (Foroughi, 2004), then deals with the constitutional concept of parliament, believing that if a government is equipped with parliament, then the government will be bound by law. Thus, the merging of parliament and the binding of the state by law, the constitution of parliament, or the democracy of parliament emerges... (Foroughi, 2004). In the 
Constitutional system of parliament, Foroughi considered the separation of powers and set out legal duties for the various powers. For Parliamentary Duties writes: the right to set the laws is conferred to a council that is called the parliament, they are the representatives of the nation and the setting of law is The right of the nation, but because the nation cannot directly do so, They give the attorney to a community to legislate and usually person of the king or the president participate in legislatory processes. Foroughi then deals with the executive branch and its duties: The head of state, whether king or president, has certain duties and has no power outside of those defined by the constitution. The government is a body that preserves justice and safeguards the system of society and fulfills this duty by setting the laws and perform them. The constitutional government is a state that setting and the implementation of laws to two separate bodies. Foroughi also considers another condition for the constitutional government, namely the observance of public law (Foroughi, 2004). In his view, public law is based on two principles: freedom, equality. He considers freedom in the possession of wealth, home, work, thought, community and association, education. (Foroughi, 2004) Then, according to the modern view, he views equality of citizens as equality in the rights of the people or equality in the law for all, and says that if there is an inequality between the people this inequality should be for the benefit of the public. He divides equality into four: in front of the law, in front of the court, in occupation and positions, and in taxation.

Another thinker who has theorized about systematization and the model of political management and belongs to the third category is Ahmad Kasravi. The result of his efforts is to establish a school or doctrine in which all things and thoughts are measured by reason. In his model, Kasravi first of all deals with the concept of government, its origin, its purpose and its necessity. He views government as the product of people's need for collective life and believes that in social life it is not possible for people to do public affairs, so there is necessary for government to do public affairs. (Kasravi, 1970). Concerning the origin of government, Kasravi implicitly refers to a social contract that is concluded between the people and if there is no such a treaty, the people of a country must assume it because such a sacred Contract is called patriotism and people must accept it (Kasravi, 1948). Like Hobbes, Kasravi views the primitive situation of society as lawless and chaotic. In order to get rid of such a situation, he thinks it necessary to form a political community. (Kasravi, 1933). Kasravi views the goal of government as protecting the masses, governing the country and ensuring the well-being of society (Kasravi, 1970). He regards the types of government in terms of historical evolution as two types: despotism and constitutional. In despotism, the foundation of government is based on authoritarianism. Autocratic rule is sometimes exercised with individual rule and sometimes with the help of the powerful. But in the constitution the basis of the government is the volition of the community, which is formed by the appointment of the rulers (Kasravi, 1970). In the point of Kasravi, constitutional government is the best form of government and the last result of human thought. In Kasravi's view, the constitutional is not just the apparent organization of the country or a constitution and parliament that the affairs of the country be done by them, rather, it requires that a nation find the quality to take over its destiny and do their own work and there is no one among them to empire (Kasravi, 1956). For Kasravi, the constitution has two aspects: national 
awareness and effective participation in government (Kasravi, 1956). Kasravi consider the difference between tyranny and constitutionalism in dominion and responsibility. In tyranny, since the people do not have the will, they also do not have responsibility for the country, there is no will for the people, but in the constitutional regime the people are free and have their own authority (Kasravi, 1956). Kasravi's other discussion of constitutional government about freedom and its boundaries. In Kasravi's view, freedom of thought is inevitable and says: What we know is to understand and free thought. (Kasravi, 1962). Kasravi views Iran's need for a constitution and a constitutional regime as inevitable. He views national governments as the sole agent of salvation and believes that national governments must be established on a firmly foundation and that the classes of the people be prepared for such a government, the parliament be elected by law and the ministers be accountable to the parliament (read Kasravi, 1948). Nationalism and love for Iran are other themes of Kasravi's thinking. In principle, he is in favor of world government while maintaining national independence. Like most Eastern scholars, he thinks with human and universal standards. He pursued his endeavors for three goals: Iran satisfaction and to cleanse Iran of intellectual and moral contamination, to save the East, and ultimately to salvation humanity. Kasravi, despite the thinking of the world government, is a nationalist when pay attention to Iranian interests and believes that Iran's independence should be the first destination (Kasravi's, 1945). Kasravi considers the elements of nationality and nationalism his language, race, religion, history, and ideals, but he considers them temporal principles, not eternal (Kasravi, Peyman Magazine, 1942).

Another person who theorized about the systematization and model of political management was Ayatollah Khomeini. He was one of the fourth class thinkers. He made a connection between religion and politics and sought the revival of religious politics and the formation of the Islamic government. The theory of Velayat-e Faqih, debate over the government, its origin and goal, freedom, categories of justice and the law are issues of interest to Ayatollah Khomeini. About the concept of justice, He consider the justice as The main condition to achieving peace, security, prosperity, independence, equality, and the goal of every government. Therefore, he believed that he would establish the Islamic government, the Islamic Republic, and Islamic Justice, and that with Islamic justice all of people will be in freedom, independence and prosperity. (Mousavi Khomeini, Sahifeye Noor: C 1,499) Another source of government for Imam Khomeini is law. In his opinion, the rule of Islam is the rule of law, and the law itself is the ruler. All are under the protection of law. All are under the protection of Islam... (Mousavi Khomeini, 1997). He divided the law into two categories: divine and customary. To him, the divine law is a set down from heaven, but the customary law is the law derived from human imperfect reason. From Khomeini's point of view, the government law is the customary law and citizens have no obligation to abide it, unless they are compatible with the divine law (Mousavi Khomeini: Sahifeye Noor, vol. 3). Liberty was another source of government in Imam's view. Imam's definition of liberty is the Verse 157 of Surah A'raf: “... and relieves them of their burden and the shackles which were upon them ..." (Quran). According to the above verse, Ayatollah Khomeini belive that the liberty is eliminate the paganism of the Muslim community and create favorable social conditions for the training of believers... (Mousavi Khomeini, Sahifeye Noor, vol 7). He divides 
governments from two perspectives based on conceptual and existing governments. Conceptual includes: Islamic or evil Governments. Evil has a tendency to make its own laws, and Islamic government is bound by God's laws. (Mousavi Khomeini, Sahifeye Noor, vol 7, 234) Ayatollah Khomeini identifies the existing governments into four categories: democracy, despotism, constitutional monarchy, and Islamic government. In his view, democracies are of two types, or formal democracy (Mohajernia, 2010, Vol 3). In despotism, the head of the dictatorial government is the one who arbitrarily interferes with the property and lives of the people (Mousavi Khomeini, 1997). Ayatollah Khomeini considers authoritarian rule to be the domination of the tyrannical spirit over the divine spirit and the domination of oppression over justice. Concerning royal constitutional government, he did not differentiate between this type of government with inherent democracy and authoritarian rule and believed that constitutionalism in its actual meaning is the ratification of law by individuals and the majority, with the role of king preserved in legislation In Islamic government, the right and power to legislate devotes to God, and there is a legislative assembly in place of, that organized the ministry in the light of Islamic law and determines the quality of public service (Mousavi Khomeini, 1997). For Khomeini, the Islamic government is a conditional government because the rulers are bound by the conditions specified in the Qoran and the Prophet's tradition. The set of conditions is the provisions of Islamic law and hence the Islamic government is the government of divine law over the people (Mousavi Khomeini, 1997). In the end, Imam Khomeini believes that the difference between governments depends on which person or persons have the highest power in government. And do they exercise power according to divine law? Power-holders have a usurpatory government if they exercise their power without regard to the provisions of the law. Therefore, So he says: We learn from the principle of belief (monotheism) the principle of human freedom, that no one has the right to deprive a person or society or a nation of freedom, to legislate for them, or regulate his behavior and relationships according to his imperfect understanding, and based on this principle, we believe that legislation is in God's will for progress, and that the happiness and perfection of man and societies depend only on obedience to divine laws. (Mousavi Khomeini, Sahifeye Noor, vol 4). Ayatollah Khomeini's other argument is that of jurisprudence, which explains it on the basis of assumptions: 1- God is the creator of the world and the owner of everything. Therefore all human beings must obey Him and not any other human being, unless his obedience is in line with obedience of God (Mousavi Khomeini, Sahifeye Noor, vol 4). 2- The sovereignty of man over his destiny is the result of his belief in the freedom and authority of man and his quasi-genuine sovereignty over his own destiny, which, by divine providence, made him free, responsible, and ruler of his own destiny In the light of which he was given the merit of the divine caliphate. 3 . In the case of human acts, God imposed some kind of indirect rule on his behavior rather than direct sovereignty over man, according to which obedience to the non-god is heresy. 4 . The nature and content of Islam's political thinking from the beginning of its beginnings, efforts and jihad were and the first step in this direction was taken by the Prophet of Islam with the formation of Islamic rule (Mousavi Khomeini, Sahifeye Noor, vol 4). 5- In Imam's view, the political movement and Islamic government of the Prophet must have continued after him and he needed to the successor (caliph) for the same position. The Prophet appointed 
successor and successors until the absence of the innocent Imam, the Imam also appointed the successor of the Imam of the Ummah, as long as the innocent Imams were present they had the right to government and after them the jurists have the right to government also (Mousavi Khomeini, Sahifeye Noor, vol 10).

Accordingly, Ayatollah Khomeini formulated the theory of Velayat-e Faqih. In his view, jurists should rule and the jurist is a person who has the power of scientific thought. According to Khomeini, anyone can rule who has a clear jurisprudential inference and is aware of the reasons for enacting laws and recognizes issues well. (Mohajernia, 2010, vol 3). Ayatollah Khomeini mentions some rational and tradition reasons for the rule of the jurist: rational reasons: in Imam's opinion: "the issue of velayat-faqih is an issue that imagination of it, necessitates to acceptance it and therefore, does not require confirmed; and what is the reason for the Imamate is also the reason to government in time of the Imam's absence (Mousavi Khomeini, Ketab al-Bie, Vol 2) Ayatollah Khomeini emphasizing on that the Islamic State is the rule of law, believed that Law experts and religious scholars should be responsible for government affairs, and therefore he restricted religious scholars to jurists. (Mousavi Khomeini, 1997). Tradition reasons include: 1- General installation of the Prophet: The Prophet at the time of his life in addition to the special installation of infallible Imams with a general installation also considered the jurists as their successors for the political leadership of the society. Numerous narrations confirm the specific installation, including the hadith of Jabir Ibn Abdullah Ansari (Tabatabai, Tafsir al-Mizan, vol. 4). Concerning the general installation, the Imam narrates with the narration of Morsaleh Saduq that the Prophet puts forward an important characteristic of his successors, who are the narrators of the hadiths: My successors are those who narrate my hadiths and traditions after my death and teach them to people. (Al-Shaykh al-Saduq, Man La Yahduruhu al-Faqih (من لايحضره الفقيه), 519. Mohajernia, 2010, Vol 3) Based on this narration, Imam believes that verily, the hadith does not include the narrators who are not jurisprudent, because the divine traditions are called the Prophet's tradition on the ground that they are revealed to him, thus, the one who wishes to distribute the Prophet's tradition, must be competent in all traditions of God (Mousavi Khomeini, 1997). Imam Khomeini rejects the application of this hadith only to the Immaculate Imams and believes: the Prophet's caliphate is not limited to specific individuals, rather, because Islamic precepts should not be abolished, so must jurists be the successors of the Prophet (Mousavi Khomeini, 1997). In addition to the above reasons, Ayatollah Khomeini cited other reasons: jurisprudents are the strong bastions (Mousavi Khomeini, Ketab al-Bie, Vol 2), the trustees (Mousavi Khomeini, Ketab al-Bie, Vol 2), the administration of the Prophet and the political leaders (Mohajernia, 2010: vol 3), responsible for the events (Mousavi Khomeini, 1997), and in control of governing matters (Mousavi Khomeini, 1997).

\section{Conclusion}

The familiarity and confrontation of Iranians with modernity has caused an intellectual, philosophical, and political crisis in Iranian society, and has produced numerous currents and discourses. Each of these discourses, on the one hand, in the face of the modern semantic system, produced thought, and on the other, by their actions, provided the ground for the creation of a discourse after themselves. New discourse, whether in the form of confronting or embracing modernity or in opposition to their earlier discourse, produced political thought. 
The scholars of each of these discourses rhad systematization or presented their political management model either in opposition to modernity and the West, either in agreement with them or in the understanding of West. Some advocated a full-fledged imitation of the West, some opposed the wholeness of the West and rejected the wholeness of the West. Some have divided the West into Western civilization and Western colonialism, advising people to adopt Western civilization and avoid Western colonization. And finally, some people have tried to redefine civilization by emphasizing on the authentic Iranian and Islamic religious and cultural traditions and by emphasizing on that they have introduced their own systematization and management model. Therefore, the thinkers of each of these currents and discourses in the face of the West and of modernity attempted to create a model, and in the framework of this pattern, both in the face of the West and in the face of the political model before them, began to produce thought; but on the other hand, they took steps to expand and consolidate their paradigm against other patterns eventually they weakened their pattern and grew their management pattern afterwards.

\section{Acknowledgments}

This article has no sponsors and no one is sponsoring it. This article has only one original author and no other authors. Another author did not help the original author in writing this article. This article does not any author or opposing views. Finally, I would like to thank the reviewers of this article.

\section{Reference}

Abadian H. (1995). Theoretical foundations of constitutional and legitimate government in Iran. Tehran: Ney Publication.

Abrahamian, E. (1979). The Causes of the Constitutional Revolution in Iran. International Journal of Middle East Studies, 10(3), 381-414. https://doi.org/10.1017/S0020743800000179

Abrahamian, E. (2005). Iran between Two Revolutions. Translated by Gol Mohammadi and Ebrahimi. Tehran: Ney Publication.

Abrahamian, E. (2012). History of Modern Iran. Fatahi translation. Tehran: Ney Publication. Adamiyat, F. (1961). Thought of Freedom and the Introduction to the Constitutional Movement. Sokhan Publications.

Adamiyat, F. (1962). Idea of Social Democracy in the Constitutional Movement of Iran. Tehran: payam Publication.

Adamiyat, F. (1971). The Thoughts of Mirza Fath-Ali Akhoundzadeh. Tehran: Kharazmi Publications.

Adamiyat, F. (1985). The Thoughts of MirzaTalibuv Tabrizi. (2nd ed.). Tehran: Damavand Publications.

Ajudani, M. (2005). Irani Constitutionalism. Tehran: Akhtaran Publishing.

Akhundzade, M. F. A. (1963). The New Alphabet and Writings. In H. Mohamadzade, \& H. Ersali (Eds). Baku: Academy of Sciences of the USSR.

Akhundzade, M. F. A. (1971). Tamsilat. Trans: Mohamad Jafar Gharachedaghi. Tehran: Kharazmi.

Akhundzade, M. F. A. (1979). Kamal al-Douleh's writings. Tehran: National Library 
prescription.

Akhundzade, M. F. A. Molhaghat. Tehran: National Library prescription. n.d.:26282.

Asil, H. (2005). Mirza Malek Khan Nazim Al-Douleh: Theorist of Modernity in Iran. Tehran: Kavir publishing.

Asil, H. (2536 Imperial Iran). An Introduction to the Thoughts of Ahmad Kasravi. Tehran: Amir Kabir Press.

Barkhordari, A. (2016). The Evolution of Iran's Contemporary Political Thought with Emphasis on the Problem of Modernity. The Social Sciences Journal, 11(29), 6954-6962.

Barkhordari, A. (2019). The Influence of Continental and Analytic Philosophy on the New Thinking of Iran. Advances in Social Sciences Research Journal, 6(3). https://doi.org/10. 14738/assrj.63.6171

Barkhordari, A. (2020). Nationalism in the Thought of the First Modern Thinkers of Iran. International Journal of Advanced Research in Management and Social Sciences, 9(3).

Foroughi, M. A. (1930). Why Iran Should Be Loved. Moody's Memoir. India: Mumbai publishing.

Foroughi, M. A. (1975). An Introduction to the Sermon of Bah ram Gaur. Tahmours Angsaria.

Foroughi, M. A. (2004). Fundamental rights mean the constitutional etiquette of states. In A. A. Haghdar (Ed). Tehran: Kavir press.

Haeri, A. H. (1985). Shia'ism and Constitutionality in Iran. Tehran: Amir Kabir press.

Haeri, A. H. (2009). The Early Intellectual Confrontation of Iran and the Two Western Bourgeois Trends. Tehran: Amir Kabir press.

Haghdar, A. A. (2004). Political Power in Iranian Thought System. Tehran: Tarh-e No press.

Haghdar, A. A. (2006). Mohamad Ali Foroughi and the New Civil Structures. Tehran: Kavir press.

Haghdar, A. A. (2009). Fereydoon Adamiyat and the History of Modernity in the Constitutional Era. Tehran: Kavir press.

Hosseinizade, M. A. (2007). Political Islam in Iran. Qom: Mofid University press.

Kasravi, A (e d). (1942). Peyman journal (Sep 1936; Feb 1940; Jul 1942). Number 13205.

Kasravi, A. (1933). Ordinance. Tehran: Armaghan publishing.

Kasravi, A. (1945). What is the solution today? Tehran: Ordibehesht publishing.

Kasravi, A. (1948). What to Do for Today. Tehran: chapak publishing.

Kasravi, A. (1956). Constitution Is the Best Form of Government and the Utmost Though of Man. Tehran.

Kasravi, A. (1958). On Wisdom. (2nd ed.) paydar publishing.

Kasravi, A. (1962). On the Way to Politics. Tehran: ferdosi publishing.

Kasravi, A. (1968). The Constitutional History of Iran. Tehran: Amir Kabir press.

Kasravi, A. (1970). Varjavand Bonyad. Tehran: Nashr-o-Pakhsh-eKetab publishing.

Laclau, E., \& Mouffe, C. (1985). Hegemony and Socialist Strategy: Toward a Radical 
Democratic Politics. London: Verso publishing.

Mohajernia, M. (2010). The Political Thought of Islamic Thinkers (Vol. 3). Tehran: Islamic Research Institute for Culture and Thought.

Mousavi Khomeini, S. R. (1964- 2000). Sahifeye Noor (Vol 1-21). Center for the Publication of Imam Khomeini's Book.

Mousavi Khomeini, S. R. (1978). Velayat. Tehran: Amir Kabir Press.

Mousavi Khomeini, S. R. (1997). Velayat-e Faqih. Tehran: Amir Kabir Press.

Mousavi Khomeini, S. R. (n.d.). Ketab al-Bie. (Vol. 2). Qom: Esmaielian publishing.

Naeini, M. H. (1982). Tanbihul- Ummahva and Tanzihul-Millah (8th ed). Introduction by Mahmoud Taleghani. Tehran: Enteshar publishing.

Qazimorad, H. (2008). Malkom Khan. (1st ed). Tehran: Akhtaran publishing. The Holy Quran. Verse of 157 of Surah A'raf.

Tabatabaei, J. (2007). The School of Tabriz and the Beginning of Constitutionality (1st ed). Tehran: Sotoudeh press.

Tabatabai, M. H. (1988). Tafsir al-Mizan. Translated by Mohammad Reza Salehi Kermani. Tehran: Raja publishing, Vol 4.

Talibuv, A. R. (1906/1324 AH). Masaelul-Hayat. Tbilisi: Qeirqt publication.

Talibuv, A. R. (1969). Masalekul-Mohsenin. Tehran: Jibi Publication.

Talibuv, A. R. (1977). the Book of Ahmad. Introduction by Baqir Mo'meni. (2nd ed.). Tehran: Shabgir Publications.

Talibuv, A. R. (1979). Politics of Talebi. In R. R. Dana (Ed.), Tehran: Science press.

Talibuv, A. R. (2015). Masalak al-Mohsenin. (2nd ed.) Tehran: Scientific and Cultural Publications.

\section{Copyright Disclaimer}

Copyright for this article is retained by the author(s), with first publication rights granted to the journal.

This is an open-access article distributed under the terms and conditions of the Creative Commons Attribution license (http://creativecommons.org/licenses/by/4.0/). 